\title{
セメント系硬化体の配合と乾燥収縮との関連
}

\section{RELATION BETWEEN MIX PROPORTION AND DRYING SHRINKAGE OF HARDENED CEMENT PASTE, MORTAR AND CONCRETE}

\author{
藤原忠司* \\ By Tadashi FUJIWARA
}

\begin{abstract}
It has been suggested that drying shrinkage of hardened cement paste, mortar and concrete is strongly related to mix proportion. The purpose of this experiment is to examine past theories about the relation between mix proportion and drying shrinkage, using many specimens made with various mix proportions.

The relations of factors of mix proportion, such as water content in the original mix, to drying shrinkage already pointed out by many investigations were also observed in this experiment over a comparatively wide range of mix proportion, except for lean mixture of extremely stiff consistency. These relations can be systematically explained by the theoretical law of drying shrinkage derived from multiphase approach. It is expected that the law can properly predict the effect of mix proportion on drying shrinkage of concrete.
\end{abstract}

Keywords : mix proportion, drying shrinkage, composite theory

\section{1. まえがき}

限界状態設計法への移行に伴い, コンクリート構造物 の設計にあたっては, 乾燥収縮の適切な評価がより一層 重要になっている.コンクリートの乾燥収縮に関する数 多い既往の研究を通覧すると, 初期には乾燥収縮に関連 する種々の要因の摘出が先行し, 最近では, それらの要 因を体系的に整理した収縮予測式の確立に重点が移って いるように思われる.提示された予測手法のいくつかは， すでに設計基準類に採用されており ${ }^{1), 21}$, 限界状態設計 法の発展に寄与するところが少なくない. しかし，それ らの手法を詳細に検討してみると，なお改良すべき箇所 がみられるとの指摘もあり ${ }^{3), 4)}$, (ま一度原点に立ち返っ て，種々の関連要因を再整理し，予測手法の信頼性を高 める努力が必要であると考えられる.

コンクリートの配合も, 乾燥収縮を支配する要因の 1 つであるのは疑いない. しかし，その関連については， 配合の因子のうちで単位水量が収縮を大きく支配すると の説をはじめ, 種々の見解が示されており, 体系的な整 理はなされていないように思われる，また，低水セメン ト比の流動化コンクリートや，ごく貧配合の RCD コン

* 正会員 工博 岩手大学助教授 工学部土木工学科 ( (020 盛岡市上田 4-3-5)
クリートなど，従来の一般的な配合を逸脱するコンク リートが実用に供されつつあり, 配合と収縮の関係をよ り広い観点からとらえる必要も生じている.

本研究では，広範囲に配合を設定した収縮試験から， 配合と収縮との関連を巨視的にとらえ，結果を従来の見 解と比較検討している. また，種々の見解を収縮に関す る複合機構の観点から統一的に解釈しようと試みてお り，さらに，実用に供されている収縮予測式の妥当性に ついても考察してみた.

\section{2. 実 験 概 要}

実験の対象としたセメント系硬化体はペースト，モル タルおよびコンクリートであり, 水セメント比と骨材容 積率との組合せにより，それらの配合を図一1に示す. コンクリートの細骨材率はすべて $45 \%$ とした。

ペースト 6 種類の配合のうち，フロー值を測定できた のは 4 種類, モルタルでは 85 種類のうち, 35 種類であっ た.また，コンクリートについても，モルタルと同じフ ロー試験を行ったところ，81 種類のうち，50 種類につ いてフロー值が得られた.フロ一值測定不可能の配合は, きわめて硬練りか，逆にきわめて軟練りであるが，配合 による収縮の違いを巨視的にとらえようとの意図のもと に，これらの配合もあえて収縮試験に用いた。したがっ 


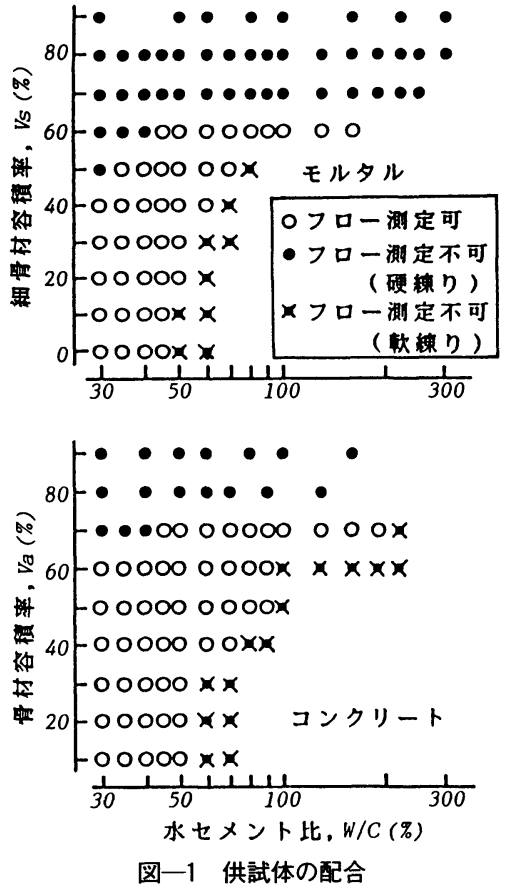

て, 配合の種類は, 総計 172 に達する.

セメントには普通ポルトランドセメント(比重 3.15), 細骨材には岩手県零石川産の砂（此重 2.54 , 吸水率 2.9 $\%$, 粗粒率 3.12) および粗骨材には同川産の砂利（比 重 2.52 , 吸水率 $3.2 \%$, 最大寸法 $15 \mathrm{~mm}$ ) を使用した。 供試体は $4 \times 4 \times 16 \mathrm{~cm}$ の角柱であり， 28 日間水中養生 後, 温度 $20^{\circ} \mathrm{C}$, 相対湿度 $60 \%$ の恒温恒湿室で乾燥させ, 長さ変化を転倒式コンパレータで測定した．検討の対象 としたのは，乾燥 105 日目の収縮値である.

実験条件から明らかなように，コンクリートについて は粗骨材の最大寸法, 供試体の寸法およびコンシステン シーの測定方法に標準的でない面があるため, 実験結果 の解析はペーストを含めたモルタルを主な対象とした。 したがって, 本結果は実用上の定量的検討に耐え得るも のではないが，多くの配合を設定した収縮試験により， 配合と収縮との関連を広い視点でとらえ，その傾向を 種々の観点から解析しようとする点に本実験の特色があ るといえる.

\section{3. 配合要因と収縮の関連}

図一2は, 本研究とは別途に行って得た貧配合コンク リートに関する実験結果 ${ }^{5}$ のうち，単位ペースト量（原 配合で全容積に占める水とセメントの容積割合）と乾燥 収縮との関係を示している.

一般に，コンクリートの乾燥収縮は単位水量に大きく 支配され，ペースト量にも比例的に対応するとされてい

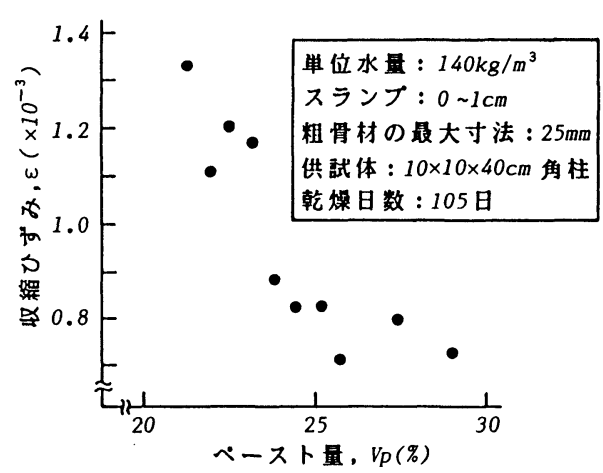

図一2 貧配合コンクリートの乾燥収縮

る.ところが, 図の結果には, 単位水量を一定としたに もかかわらず，収縮に比較的大きな差が見受けられ，し かもその収縮はペースト量と逆比例の傾向にある.この 結果は, 従前の一般的な配合を逸脱するコンクリートの 場合，その収縮も一般的概念に適合しない可能性のある ことを示唆する例と考えられよう.

本実験で得たすべての結果を用い, 単位水量と収縮と の関連を求めたのが図一3である.

硬化体の種類にかかわらず, フロー值測定可能の配合 およびきわめて軟練りの配合に関しては, 水セメント比 等が異なっても, 各測定値はほぼ同一線上に位置してい るから, 単位水量が収縮の支配的要因であるのは疑いな い.これらの配合領域では, 従来から指摘されてきたよ うに6)，単位水量をできるだけ小さく抑えるのが，収縮 を小さくし, ひびわれ発生を防ぐ要訣といえる.

他方, 極端に硬練りの配合の場合は, 他の傾向から外 れ，単位水量の割に比較的大きな収縮を示すことに注意 を要する.これらの配合領域では, 流動性の欠如によっ て供試体の空隙が多く, 強度も低いため変形に対する抵 抗能力が小さいと考えられ, 単位水量の選定にはこの点 への配慮が必要となろう.

図一4 は, 単位ペース卜量と収縮との関連を示してい る.

この関係については, 直線的に比例するとしている例 が多く7), 本結果でも, ペース卜量の中間領域では, そ の関係がほぼ成り立つ.しかし，全体的には指数関数的 な傾向を示しており，またペースト量の少ない硬練りの 領域では, その傾向からも外れる. 図一2にみられる結 果は, この領域の範疇にあると推察される.

図一3および図一4から明らかなように，モルタルと コンクリートとでは，その傾向にほとんど差がない，そ こで，以後は，ペーストを含めたモルタルにのみ着目す ることにする.

単位セメント量当たりの収縮を単位収縮とよぶことに すれば，これは図一5のように，フロー值測定可能の配 


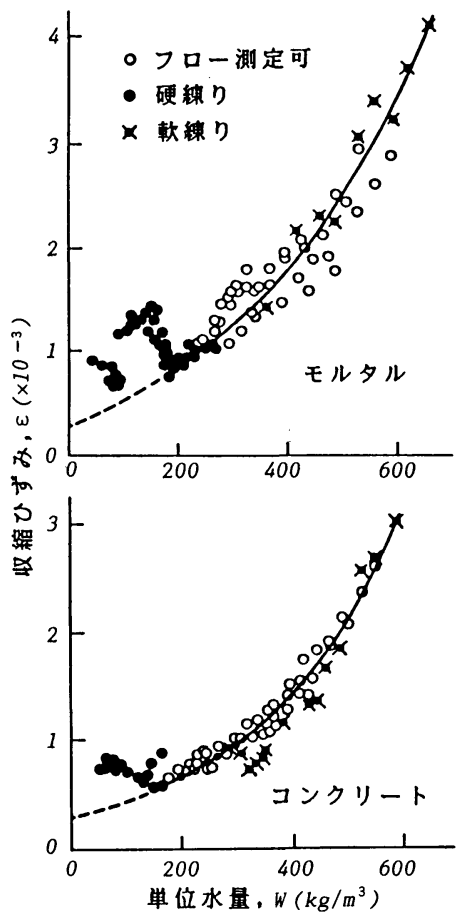

図一3 単位水量と収縮の関係
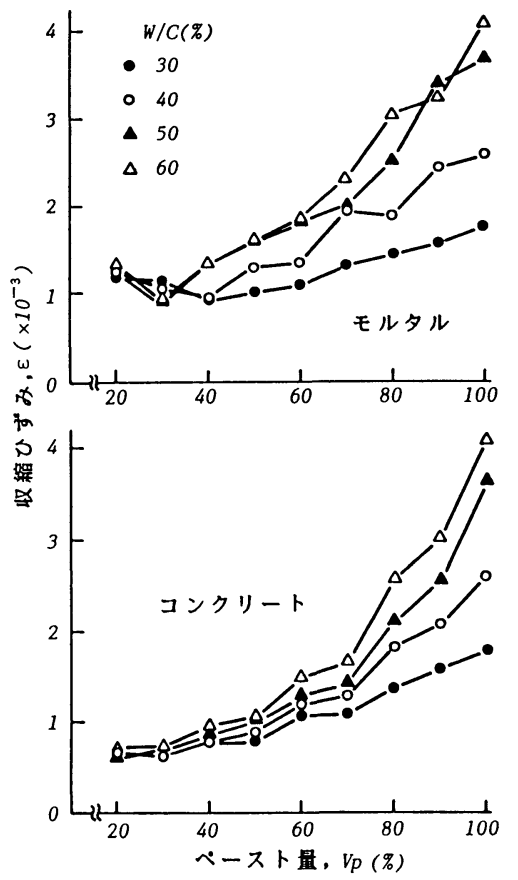

図一4ペースト量と収縮の関係

合領域で, ペースト量にかかわりなく, 水セメント比と きわめて良好な直線関係にあり，実験式は次のようにな

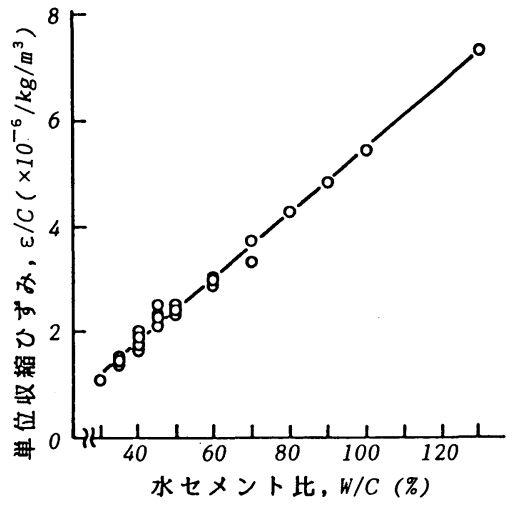

図一 5 水セメント比と単位水量の関係

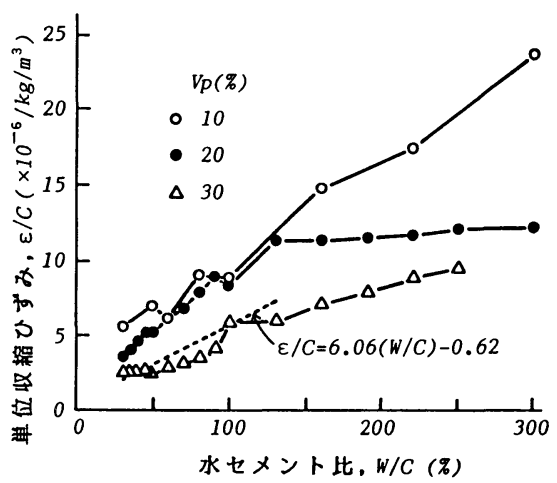

図一 6 水セメント比と単位収縮の関係

る.

$$
\begin{aligned}
& \varepsilon_{m} / C=6.06(W / C)-0.62 \\
& \varepsilon_{m}=6.06 W-0.62 C \cdots \cdots
\end{aligned}
$$

ここに, $\varepsilon_{m}$ : モルタルの収縮ひずみ $\left(\times 10^{-6}\right), W$ : 単 位水量 $\left(\mathrm{kg} / \mathrm{m}^{3}\right), C$ : 単位セメント量 $\left(\mathrm{kg} / \mathrm{m}^{3}\right)$

式（2）の係数からも，収縮は単位水量に大きく支配 されるのが認められる.この関係は，すでにいくつかの 研究 ${ }^{8)}$ によって明らかにされているが，これが成り立つ のは本実験の場合, フロー值測定可能の配合に限られて おり, 特にきわめて硬練りの配合では, 図一6ように, この直線から大きく逸脱し, 過大な単位収縮を示す.

収縮を単位セメント量との関連でとらえたのが図一7 である。

水セメント比が同一であれば, 収縮は単位セメント量 の大きいほど著しい傾向がみられる．この傾向もすでに 指摘されている ${ }^{91}$ が, きわめて硬練りの場合は, 例外之 みなさなければならない.なお，図に示されるように， 単位水量が同一であれば，収縮に著しい差がみられず， この結果も単位水量の重要性を際だたせている.

以上の結果は, きわめて硬練りの配合を除き, 配合と 収縮について従来から明らかにされてきた関係が, 比較 


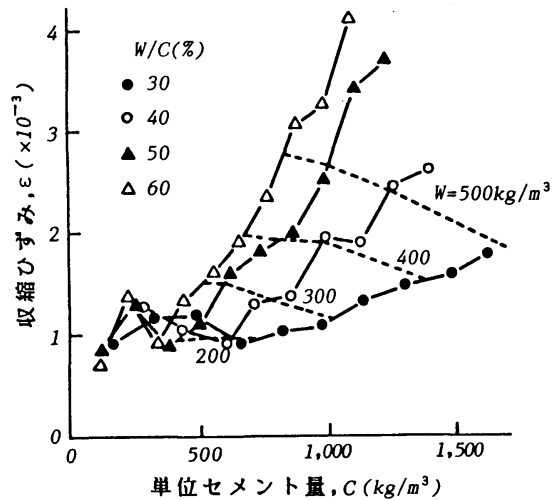

図一7 単位セメント量と収縮の関係

的広い配合領域にわたって成り立つことを示している. 収縮に関連する配合の各種要因のうち, これらの配合領 域では, 単位水量が最も支配的であり, 収縮を低く抑え るには，この要因に格別の配慮をしなければならない. しかし, 収縮は単位水量以外にも, 水セメント比や単位 ペースト量などとも一定の関係にあるため，収縮予測の 手法にこれらの要因をいかに組み込むかは, 難しい課題 であるといえる.

\section{4. 収縮予測手法の検討}

土木学会コンクリート標準示方書には, “コンクリー トの乾燥収縮は, 構造物の周辺の湿度, 部材断面の形状 寸法，コンクリートの配合などを考虑して，これを定め ることを原則とする”と規定され，通常のコンクリート における標準的な值が, 屋外および屋内別に乾燥開始材 令に応じて与えられている. そして, その解説では, 環 境の湿度, 部材寸法の影響を加味して収縮ひずみの大き さや進行速度を求める場合には; 次式を用いてもよいと している.

$$
\varepsilon_{c s}^{\prime}\left(t, t_{0}\right)=\varepsilon_{s 0}^{\prime}\left[\beta_{s}(t)-\beta_{s}\left(t_{0}\right)\right]
$$

ここに, $\varepsilon_{c s}^{\prime}\left(t, t_{0}\right):$ コンクリートの材令 $t_{0}$ から $t$ まで の乾燥収縮ひずみ, $\beta_{s}(t)$ : コンクリートの材令および 部材の仮想厚さに関する係数

配合の影響については，これを原則的に考慮するとし ながらも，標準值および式（3）に組み込んでいない. ただし，解説において，配合の違いによる収縮の差が大 きいことを認め, 標準より軟練りのコンクリートに対し ては，収縮値を増すのがよいとしている，

示方書の解説は CEB-FIP 国際設計施工指針（1976） によっており，この指針は Rüsch の提案 ${ }^{1}$ を採用したも のである. 旧指針では水セメント比とセメント量の影響 を考虑していたが, 通常の構造用コンクリートでは設定 する水セメント比の範囲が限られていることから, セメ ント量のみに着目し,これがコンシステンシーに関係す

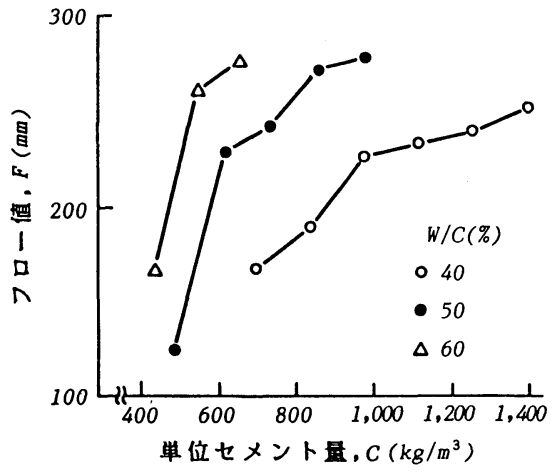

図一8 単位セメント量とフロー值の関係

るため，配合の影響を簡略化して，コンシステンシーだ けで表示しようとするのが提案の特徵となっている. 具 体的には，軟練りおよび硬練りのコンクリートに対し， 基本乾燥収縮度をそれぞれ約 $25 \%$ 増減する。

図一8 は，単位セメント量とフロー值の関係を示して いる.

水セメント比が同一であれば，両者に一定の関係がみ られ，セメント量の代わりとして，コンシステンシーに 着目しようとした Rüsch の意図はほぼ妥当であるとい える．ただし，フロー値は水セメント比の違いに比較的 敏感である点に注意を要する.

フロー值と収縮の関係を求めたのが図一9である.

大略的には，収縮がフロ一值に比例しており，収縮に 及ぼす配合の影響をコンシステンシーによって表示した Rüsch の予測手法の妥当性がうかがわれる，いま，フ ロ一值の範囲を三等分することによって，それぞれ硬・ 中・軟練りと仮定し, 中間領域における収縮值の平均( ほ ぼ $\left.1.6 \times 10^{-3}\right)$ を基準とすれば，その $\pm 25 \%$ の収縮值 は図のようになる，硬練りの領域に関しては，25\% 減 の収縮値でほぼ妥当であるのに対し,軟練りの領域では,

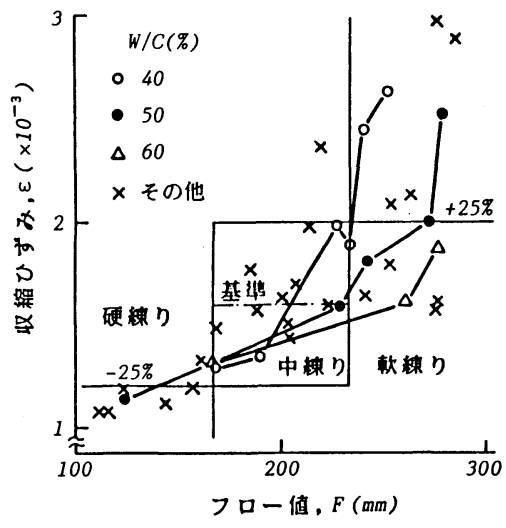

図一9 フロー值と収縮の関係 
$25 \%$ 増の収縮値に比し，大きくかけ離れる実測值が少 なくない。これは, 特に軟練りの領域において, フロー 值と収縮が比例関係から大きくばらつくためであり， Ruisch の予測手法に改良の余地があるのを示唆してい ると考えられる.

単位セメント量当たりのフロー值を単位フロー値とよ ぶことにすれば，これは図一10のように，ペースト量 にかかわらず，水セメント比ときわめて相関の高い次の ような直線関係にある。

$F / C=0.96(W / C)-0.17$

ここに, $F$ : フロー値 $(\mathrm{mm})$

この単位フロー值と, 既述の単位収縮との関係を求め たのが図一11である。

Rüsch の提唱する図一9 の関係と比較すれば，きわめ て良好な直線関係が成立しており，実験式は次のように なる。

$$
\begin{aligned}
& \varepsilon_{m} / C=6.34(F / C)+0.44 \\
& \varepsilon_{m}=6.34 F+0.44 C \cdots \cdots
\end{aligned}
$$

上式は，フロー値によって収縮がほぼ決定されるもの の，これに単位セメント量を加味すれば，さらにその相 関が向上することを意味している．式（5）に式（4) を代入すると，次式が得られる.

$$
\varepsilon_{m} / C=6.34\{0.96(W / C)-0.17\}
$$$$
=6.08(W / C)-0.64
$$

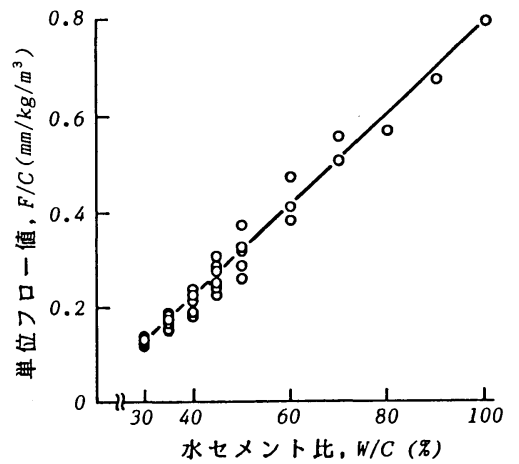

図一10 水セメント比と単位フロー值の関係

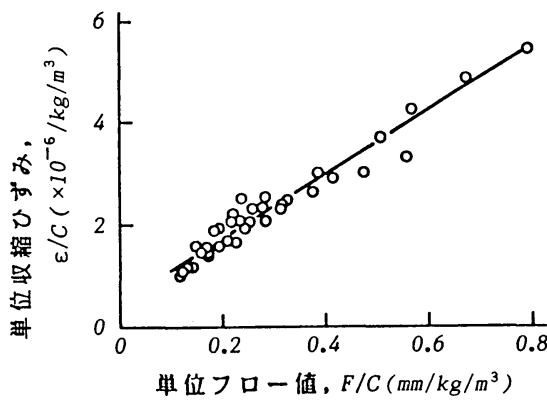

図一11 単位フロー值と単位収縮の関係

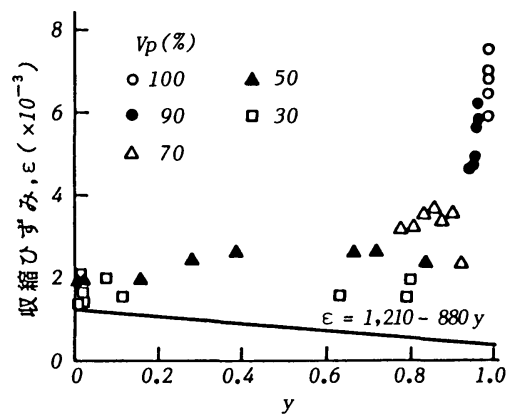

図一12 Bažant 式の検討

この式は, 前出の式（1）にほぼ等しく, 結局は収縮 が単位水量に支配され，次いで単位セメント量に影響さ れるという表示に帰着する。したがって，コンシステン シーに着目するよりは，配合の要因のみによって収縮を 予測できる式（1）の形で配合の影響を表示するのが, 便宜的かつ合理的であると考えられよう.

土木学会コンクリート標準示方書の解説では, Rüsch の式以外にも, Bažant の式および ACI-209 委員会の式 などが適用範囲の広い式であり，目的に応じてこれらを

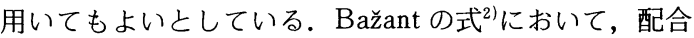
の影響に関する部分だけを取り出せば，次の形になる.

$$
\begin{aligned}
& \varepsilon_{s}=1210-880 y \\
& y=\left(390 z^{-4}+1\right)^{-1} \\
& z=\left\{1.25(A / C)^{1 / 2}+0.5(G / S)^{2}\right\} \\
& \cdot\{(1+S / C) /(W / C)\}^{1 / 3} \cdot f_{c}^{\prime 1 / 2}-12
\end{aligned}
$$

ここに, $\varepsilon_{s}$ : 相対湿度 $0 \%$ での終局収縮ひずみ $\left(\times 10^{-6}\right)$, $A / C$ : 骨材セメント重量比, $G / S$ : 粗骨材と細骨材の 重量比, $S / C$ : 細骨材セメント重量比, $W / C$ : 水セメ ント重量比, $f_{c}^{\prime}$ : コンクリートの 28 日材令圧縮強度 (ksi)

上式は，既往の多数の実験デー夕を用いた最適化法に よって導かれており, 収縮に関連すると思われる配合要 因のほとんどを組み込んでいる，本実験のモルタルの条 件をあてはめて式（9）の $y$ を計算し，これと供試体 絶乾後の収縮值との関係を求めたのが図一12 である.

ペースト量の大きい配合に関しては，両者に明確な関 係が見受けられない。 また，ペースト量が 50 \% および $30 \%$ の配合に関しても, 収縮值は横軸にほぼ平行であっ て, 式 (8) から期待される $y$ との逆比例の関係は成 立しない. 類似の傾向は, コンクリートを対象として行っ た他の研究例 ${ }^{3)}$ (4)でも指摘されており, Bažant の収縮予 測式における配合の影響に関する部分は，再検討の余地 があると考えられる。

\section{5. 複合則による検討}

前述のように，収縮には配合の各種要因がそれぞれ独 
自の形で関連する. Bažant の予测式は,これらの要因 を最適化しようとの試みであろうが，その現実への適合 性は必ずしも良好とは思われない. 収縮予測の 1 つの手 法は, コンクリートを複合材料と考え, 収縮現象を力学 的に解析して, 収縮の複合則を利用するものであろう. この試みはすでに多くの研究者によってなされており, その中では, Pickett の式 ${ }^{10)}$ が最もよく引用される.こ れをモルタルに適用すれば，次のようになる.

$$
\begin{gathered}
\varepsilon_{m}=\varepsilon_{p}\left(1-V_{s}\right)^{\alpha}=\varepsilon_{p} V_{p}^{\alpha} \ldots \ldots \ldots \ldots \ldots \\
\alpha=\frac{3\left(1-\nu_{m}\right)}{1+\nu_{m}+2\left(1-2 \nu_{s}\right) E_{m} / E_{s}}
\end{gathered}
$$

ここに， $\varepsilon_{p}$ : ペーストの収縮 $\left(\times 10^{-6}\right), V_{s}$ : 細骨材の 容積率, $V_{\rho}$ : ペーストの容積率, $\nu_{m}$ : モルタルのポア ソン比, $\nu_{s}$ : 細骨材のポアンン比, $E_{m}$ : モルタルの弾 性係数 $\left(\mathrm{kgf} / \mathrm{cm}^{2}\right), E_{s}$ : 細骨材の弾性係数 $\left(\mathrm{kgf} / \mathrm{cm}^{2}\right)$

この式は, モルタルの収縮が, ペーストの収縮とペー スト量によって基本的に決定されることを意味してい る.たとえば, 水セメント比が同一の場合, ペーストの 収縮は一定と考えられるので, モルタルの収縮はペース 卜量の指数関数亡なるのがうかがわれるが, 図一-4の実 験結果は,この予想どおりの傾向を示しているといえる. このように, 複合則を配合要因の観点から解析すること により，従来提示されてきた配合要因と収縮に関する 種々の見解を統一的に説明でき, さらには収縮予測手法 に配合要因の影響を合理的に組み込む可能性が生じると 予見される.

Pickett 式は, 指数 $\alpha$ に複合体としての $E_{m} や \nu_{m}$ を含 み, 本来構成要素の性質のみで表示すべきである複合則 としての体をなしていない, また,この式では, 骨材自 体の収縮を看過しており，この点にも問題があると考え られる ${ }^{11)}$.このような難点を解消し, 現実への適合性を 改良したと思われるのが, 次の Hansen らの式 ${ }^{12)} ゙$ ある.

$$
\begin{aligned}
& \frac{\varepsilon_{m}}{\varepsilon_{p}}=(1-m) \frac{n+1+(n-1) V_{s}{ }^{2}-2 n V_{s}}{n+1}+m \quad(n \geqq 1) \\
& \cdots \cdots \cdots \cdots \cdots \cdots \cdots \cdots \cdots \cdots \cdots \cdots \cdots \cdots \cdots \cdots \cdots \cdots \cdots \cdots \cdots(12) \\
& \frac{\varepsilon_{m}}{\varepsilon_{p}}=(1-m) \frac{n+1-(n+1) V_{s}}{n+1+(n-1) V_{s}}+m \quad(n \leqq 1) \cdots(13) \\
& n=E_{a} / E_{p}, \quad m=\varepsilon_{s} / \varepsilon_{p}
\end{aligned}
$$

ここに, $E_{p}$ : ペーストの弾性係数 $\left(\mathrm{kgf} / \mathrm{cm}^{2}\right), \varepsilon_{s}$ : 細 骨材の収縮 $\left(\times 10^{-6}\right)$

上式に含まれる因子のうち, ペーストの収縮 $\varepsilon_{p}$ は, 図一13のように水セメント比とほぼ直線関係にあり, 実験式は次のように表示される.

$$
\varepsilon_{p}=67(W / C)
$$

一方, 細骨材の収縮 $\varepsilon_{s}$ は, 配合と無関係であり, こ れを考慮することは本課題の範囲を冕脱している感がな くもないが, 配合の決定の際に使用材料の性質をとらえ

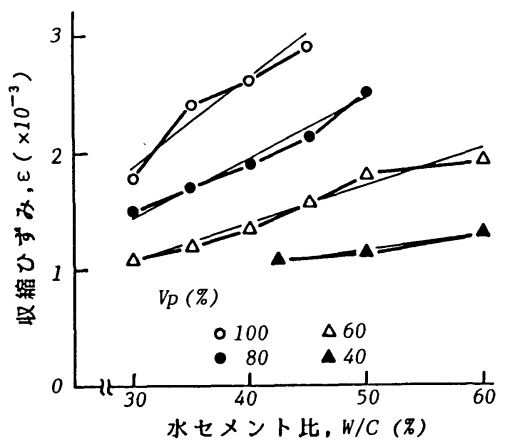

図一13 水セメント比と収縮の関係

ておくのは必須の前提であるから，収縮予測式にも，使 用材料の性質を配合の部分に組み入れるのが妥当であろ う.

従来, コンクリートの収縮をもたらす主たる能動要因 はペーストの収縮であるとして, 骨材自体の収縮を一般 に無視してきた.土木学会コンクリート標準示方書でも, 骨材の性質がコンクリートの収縮に影響するとしながら も，その関連を具体的に示してはいない。 また，前述の Rüsch や Bažant の予測式にも，骨材自体の収縮への配 慮はみられない.しかしながら，骨材自体の収縮は決し て看過できるものではなく ${ }^{11)}$ ，コンクリートの収縮への 影響もまた無視できない吕,13).ことにも，骨材の低品質 化が叫ばれている今日，骨材自体の収縮がコンクリート の収縮を過大にする懸念が強まっており ${ }^{14)}$, その意味で, この影響を考慮している複合則は, より有用性の高い表 示であると考えられる.

細骨材自体の収縮については，測定が難しいため，こ こでは図一3においてきわめて硬練りの配合を除いたモ ルタルの収縮傾向から, $W=0$ の值を採用し, $\varepsilon_{s}=300$ $\times 10^{-6}$ と仮定してみた。

細骨材の弾性係数も実測が難しいため, 次の Hansen らの複合式 ${ }^{15)}$ を用い，モルタルおよびペーストの弾性係 数測定結果から算出した.

$$
\frac{E_{m}}{E_{p}}=\frac{n+1+(n-1) V_{s}}{n+1-(n-1) V_{s}}
$$

以上の点を考慮すると, Hansen らの式は次のように なる.

$$
\begin{aligned}
& \varepsilon_{m}=67(W / C)\left\{1-\frac{300}{67(W / C)}\right\} \\
& \cdot \frac{n+1+(n-1) V_{s}{ }^{2}-2 n V_{s}}{n+1}+300 \quad(n \geqq 1) \\
& \varepsilon_{m}=67(W / C)\left\{1-\frac{300}{67(W / C)}\right\} \frac{n+1-(n+1) V_{s}}{n+1+(n-1) V_{s}} \\
& +300 \quad(n \leqq 1)
\end{aligned}
$$




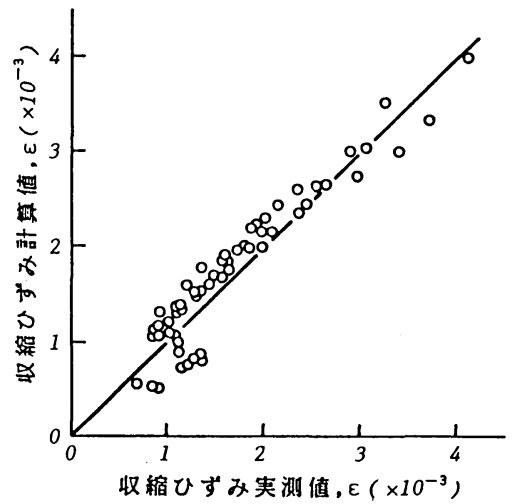

図一14 Hansen 式の検討

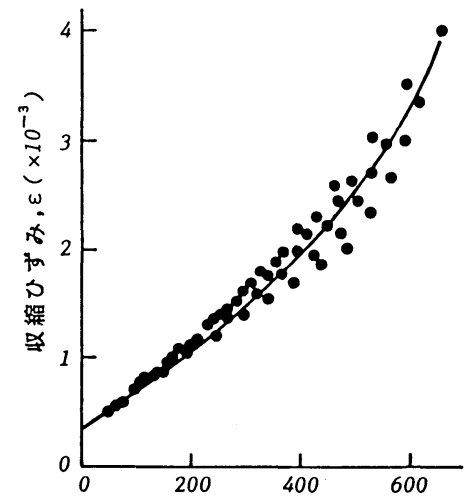

單位水是, $W\left(\mathrm{~kg} / \mathrm{m}^{3}\right)$

図一15 単位水量と収縮の関係（計算値）

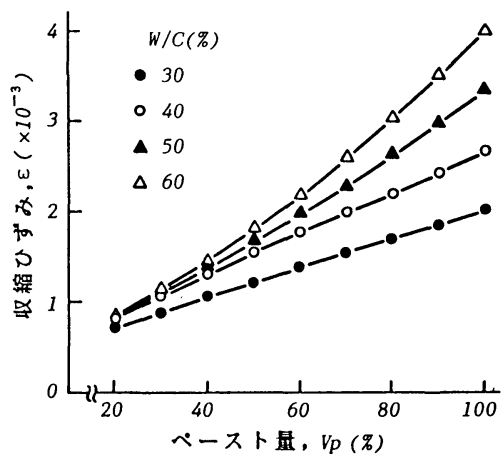

図一16 ペースト量と収縮の関係（計算値）

図一14 は上式の適合性を検討したものであり，ごく 硬練りの配合を除き，計算值は実測値とおおむね一致し ている.この計算值を配合の諸要因との関連でとらえた のが図一15〜19である.

これらの図をそれぞれ対応する図一 $3,4,5,7,13$ と 比較するならば, 細部に検討の余地は残るものの, 計算 值が実測值の傾向をよくとらえているのが認められよ う.この結果は, 単一の配合要因のみによって収縮を説

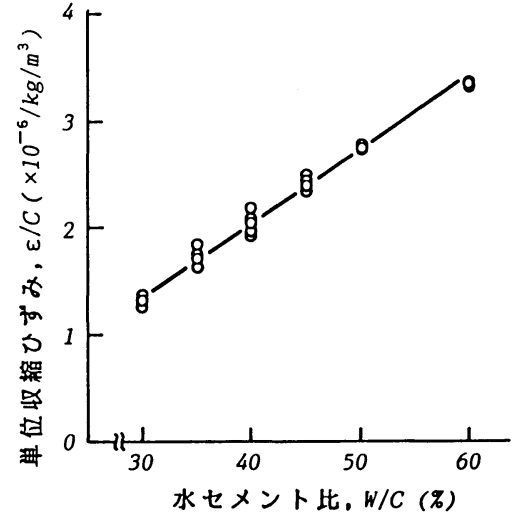

図一17 水セメント比と単位収縮の関係（計算値）

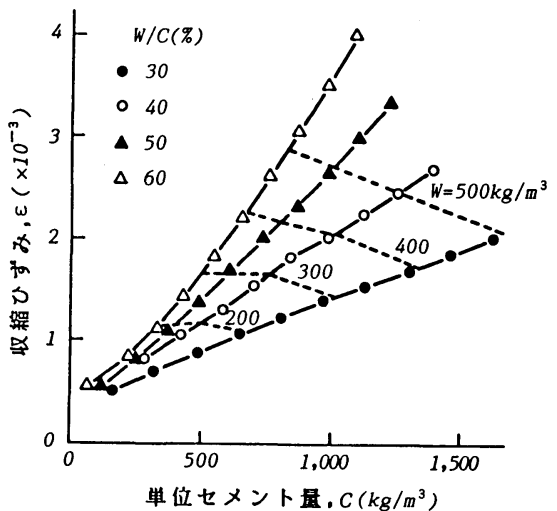

図一18 単位セメント量と収縮の関係（計算値）

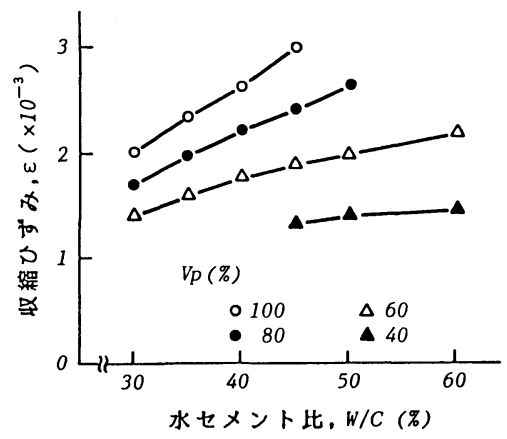

図一19 水セメント比と収縮の関係（計算値

明しようとした従来の見解が，収縮の複合則によって統 一的に解釈され得ることを示している.

換言すれば,従来の見解を包括した形の上記複合則は， 収縮に及ぼす配合の影響を的確に表示しており，しかも それは使用材料の性質をも考慮しているから，収縮予測 の手法に十分耐え得る性格を有していると考えられる. ただし, 複合則の中には, 一般に測定が難しい因子も含 まれており，このままの形では実用に供しにくい。これ 
らのうち, ペーストの弾性係数は, 図一20のように, セメント水比と一定の関係がみられるから，次のように 表示できる.

$$
E_{p}=f(C / W)
$$

次に，骨材の弾性係数については，本実験とは別途に 行った砕石に関する実験において，図一21のように吸 水率との間に明確な関係が存在しており, 次の式が成り 立つ.

$$
E_{a}=f\left(w_{a}\right)
$$

ここに, $E_{a}:$ 骨材の弾性係数, $w_{a}$ : 骨材の吸水率

骨材自体の収縮は, 内部の比表面積と比例関係にあ

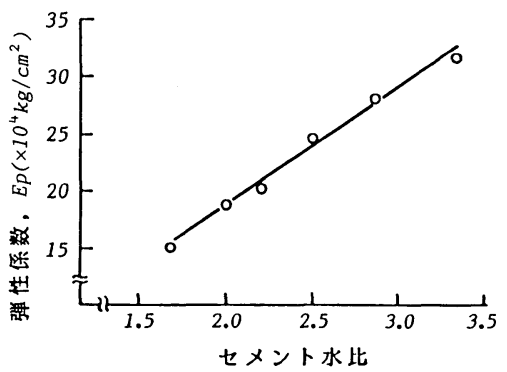

図一20 ペーストのセメント水比と弾性係数の関係

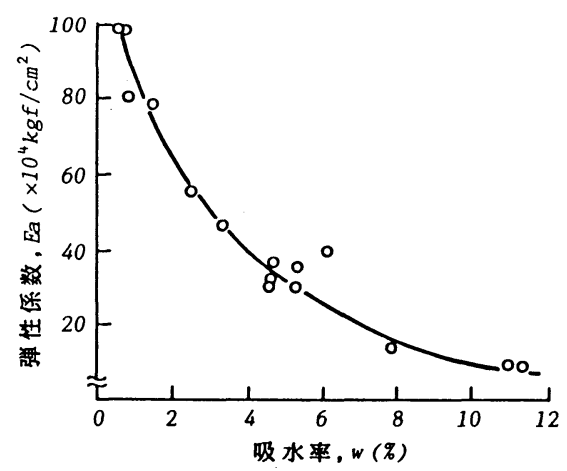

図一21 骨材の吸水率と弾性係数の関係

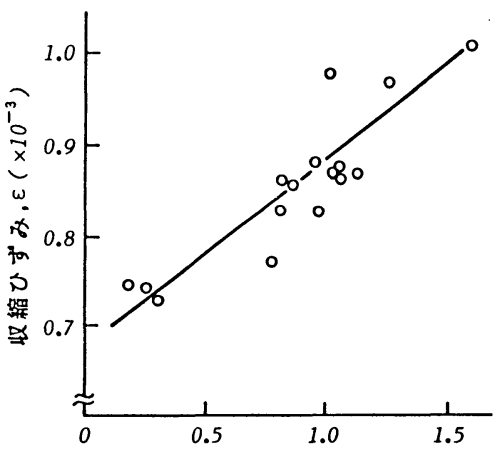

吸湿率, $w^{\prime}(\%)$

図一22＼cjkstart砂利の吸湿率とコンクリートの乾燥収縮との関係
る ${ }^{11)}$.しかし，この実測は容易でないため，これに代わ る指標として, 表面積に密接にかかわると思われる吸湿 率（絶乾状態の骨材を相対湿度 $100 \%$ の空気中に 24 時 間放置したときの吸湿率) に着目してみたい.

図一22も，本実験とは別途に行って得た結果であり， 砂利の吸湿率とこれを用いたコンクリートの収縮との関 係を示している ${ }^{14)}$.

両者に明確な直線関係が成立し，骨材の吸湿率がコン クリートの収縮に関連するのは疑いない.この実験では, 各コンクリートの違いが用いた砂利の性質のみであるか ら，この結果は，骨材自体の収縮が吸湿率に密接に関連 することを示しているとして差し支えなかろう.した がって, 次式のように表示できる. なお, 吸湿率は容易 に測定できる物理量である.

$$
\varepsilon=f\left(w_{a}^{\prime}\right) \cdots
$$

ここに， $\varepsilon_{a}$ : 骨材の収縮, $w_{a}^{\prime}$ : 骨材の吸湿率

式（18）（20）を式（12）および（13）に代入すれば, 複合体の収縮は，配合の要因と使用材料の基本的物性に よって表示されることになる. 式（18）（20）の関数形 を定式化するには，多くの実験を要し，また本実験では 骨材の種類が限定されているため, 最終的な式の妥当性 を検討できないが，収縮予測式に配合ならびに使用材料 の性質の影響を組み込むには，ここで示した方法が有用 であると期待される。

\section{6. あとがき}

本文では，ペーストを含めたモルタルを主体として解 析しているため，コンクリートの配合と収縮との関連を 定量的に検討できないが，定性的な傾向としては，次の ような点を指摘できると考えられる.

（1）配合の各種要因と収縮の関係について，比較的 広い配合領域にわたり，従来から指摘されている傾向が みられた．ただし，きわめて硬練りの配合の場合には， この傾向から逸脱して大きな収縮を示すため, 注意を要 する.

（2）従来から提示されている種々の見解は, 収縮の 複合則により統一的に解釈できると考えられる.

（3）収縮予測手法としての Rüsch の式では, 配合 の影響要因としてコンシステンシーを取り上げており, これは基本的に妥当と思われる.ただし，コンシステン シーよりは，単位水量と単位セメント量の組合せで表示 するのがより合理的と考えられる実験結果が得られた。 また，種々の配合要因の組合せで配合の影響を評価しよ うとす Bažant の予測式は，本実験結果との適合性が よくない.

（4）配合の影響を評価するには，収縮に関する複合 則を利用するのが合理的でかつ精度も優れていると提唱 
できる．この複合則には，配合要因のほかに使用材料の 性質も考慮されており, 特に骨材の低品質化の傾向がみ られる今日では，より有用であると考えられる，ただし， この方向での予測式を実用的なものとして確立するため には，解明すべき課題が残されている.

\section{参 考 文 献}

1) Rüsch, H. and Jungwirth, D. (百島祐信訳) : コンク リート構造物のクリープと乾燥収縮, 鹿島出版会, 1976.

2) Bažant, Z.P. and Panula, L. : Practical prediction of Time-Dependent Deformations of Concrete, Materiaux ET Constructions, Vol. 11, No. 75, pp. 307 316, 1979.

3）生谷征美：コンクリートの乾燥収縮に及ぼす諸要因の影 響と収縮量予測に関する実験的研究, 学位論文, 1983.

4）阪田憲次：コンクリートの乾燥収縮およびクリープの予 測, セメント・コンクリート, No. 425, pp. 7〜13, 1982.

5）森島啓行・藤原忠司：貧配合コンクリートに関する一実 験, 昭和 53 年度土木学会東北支部技術研究発表会講演概 要, 1973.

6）米国内務省開拓局編（近藤泰夫訳）：コンクリートマニュ アル，国民科学社，pp. 13 14，1966.

7) Lyse, I. : Shrinkage and Creep of Concrete, Jour. of
ACI, Vol.56, pp. 775 786, 1960.

8）日本セメント研究所：コンクリートの配合と乾燥収縮と の関係について, セメント工業, No. 131, pp. 19 22, 1974.

9) Czernin, W. (徳根吉郎訳) : セメントコンクリート化 学, 技報堂, p. 113, 1969 .

10) Pickett, G. : Effect of Aggregate on Shrinkage of Concrete and Hypothesis Concerning Shrinkage, Jour. of ACI, Vol.52, No. 5, pp. 581 590, 1956.

11）後藤幸正・藤原忠司：乾湿に伴う骨材の体積変化, 土木 学会論文報告集, No. 247, pp. 97 108, 1976.

12) Hansen, T.C. and Nielsen, K. E. C. : Infuluence of Aggregate Properties on Concrete Shrinkage, Jour. of ACI, Vol. 62, No. 7, pp.783 794, 1965.

13）後藤幸正・藤原忠司：コンクリートの乾燥収縮に及ぼす 骨材の影響, 土木学会論文報告集, No. 286, pp. 125 137, 1979.

14）藤原忠司：低品質の粗骨材を用いたコンクリートの諸性 質，セメント・コンクリート, No. 481, pp. 8〜15, 1987.

15) Hansen, T. C. : Influence of Aggregate and Voids on the Modulus of Elasticity of Concrete, Cement Mortar and Cement Paste, Jour. of ACI, Vol.62, pp. 193 216, 1965.

（1987.8.6 - 受付） 